\title{
Perch substrate use of the threatened wallum sedge frog (Litoria olongburensis) in wetland habitats of mainland eastern Australia
}

\begin{abstract}
Understanding habitat requirements for a threatened species is important for recovery planning and management of threatening processes. This study examines utilisation of wetland habitat by the threatened wallum sedge frog (Litoria olongburensis), which breeds in acidic waters of coastal sandy lowlands in subtropical eastern Australia. Habitat utilisation was determined by comparing perch substrate observations with perch substrate availability in wetlands occupied by the species' throughout its mainland distribution range. A high proportion (75.3\%) of adult wallum sedge frogs was perched on upright sedges, comprising Baumea, Schoenus and Chorizandra species, which was much higher than expected based on availability $(\mathrm{p}<0.001)$. Baloskion pallens, a thin sedge-like herbaceous plant, was utilised by $12.1 \%$ of the frogs, which was lower than expected based on availability $(\mathrm{p}=0.020)$. Other herbaceous species and shrubs were also utilised significantly less than expected. The identification of preferred perch species is critical for impact assessment and mitigation activities, including design, construction, restoration and maintenance of wetlands suitable for the survival and reproduction of the wallum sedge frog.

\section{Introduction}

Understanding habitat use for a threatened species assists with recovery planning and management of threatening processes for the species (e.g. Meyer et al. 2006). Some frog species use particular plant species (Beard et al. 2003; Watson et al. 2003) or structural components in a vegetation community (Parris 2001; Beard et al. 2003). For example, Lüddecke et al. (2000) found that four terrestrial frogs in a neotropical community used different plant species as calling 
Perch substrate use of Litoria olongburensis

sites. Availability of particular plant species or vegetation structures may therefore influence survival and reproduction of some frog species.

The present study explores use of habitat by the wallum sedge frog (Litoria olongburensis Liem \& Ingram, 1977), which breeds in low $\mathrm{pH}$ waters of coastal sandy lowlands in subtropical eastern Australia (Ingram and Corben 1975). The wallum sedge frog is considered threatened throughout its geographic range, being listed as 'vulnerable' under the Commonwealth's Environmental Protection and Biodiversity Conservation Act 1999, Queensland's Nature Conservation Act 1992 and New South Wales’ Threatened Species Conservation Act 1995. Habitat loss and fragmentation are considered to be the main threats to the species (Ehmann 1997; Hines et al. 1999; Meyer et al. 2006). Mortality on roads that traverse habitat has also been identified as a threat (Goldingay and Taylor 2006). Various authors have reported that the wallum sedge frog is found among emergent vegetation in wallum wetlands (Ingram and Corben 1975; Liem and Ingram 1977; Ehmann 1997; Lewis and Goldingay 2005). However, association of the wallum sedge frog with individual plant species, or structural components, within the frog's habitat has not been identified. The present study investigates breeding habitat utilisation of the wallum sedge frog by comparing perch observations with perch availability in wetlands throughout its mainland range.

\section{Materials and methods}

\section{Field methods}

Records of wallum sedge frog sightings collated by Meyer et al. (2006) were used to select survey areas spread throughout the geographic range of the species on the Australian mainland, from Great Sandy National Park (Cooloola Recreation Area), Queensland, in the north to Yuraygir National Park, New South Wales, in the south (Fig. 1). In Queensland, Fraser Island and the islands of Moreton Bay were excluded from the scope of this study, due to limits on time 
and resources. For each survey area, one or more lines were used to search for waterbodies. Each search line captured at least one location at which the wallum sedge frog has been recorded. All search lines were placed within the coastal wallum landscape and, in total, they captured the most common wetland communities recorded in wallum landscapes (Griffith et al. 2003; DERM 2005). To capture variation along salinity gradients, search lines were aligned perpendicular to the coastline, or as near to perpendicular as practical within the constraints of surrounding anthropogenic disturbances. Using a Global Positioning System (GPS) receiver (Trimble® Juno $^{\mathrm{TM}} \mathrm{SC}$ ) for guidance, the search line was followed and every waterbody encountered was surveyed. The maximum time allowed on each line was two days. Distances searched along the lines therefore differed in response to individual site characteristics, such as the size and frequency of waterbodies, and vegetation density (see Results section for the resulting distances). For the purposes of this study, any wetland with standing water was considered to be a waterbody. This definition includes swamps that consist of a collection of small disconnected pools.

For each waterbody encountered along the search line, one or more (depending on waterbody size) line transects were surveyed. For relatively small waterbodies, a single transect crossed the waterbody from edge to edge, passing through the deepest part of the waterbody, or as near as practical. Transect lengths for these smaller waterbodies ranged from 59 to $200 \mathrm{~m}(\mathrm{n}=14)$. For larger waterbodies, a single edge-to-edge transect was not practical. These larger waterbodies had two or three distinct vegetation zones, and a transect was placed in each zone (perpendicular to the vegetation gradient). Total length of transects in these larger waterbodies ranged from 184 to $316 \mathrm{~m}(\mathrm{n}=5)$.

For each waterbody transect, vegetation species cover was measured using five quadrats (each 5 $\mathrm{m} \times 5 \mathrm{~m}$ ) equally spaced along the transect, except for one transect where only three quadrats 
were used due to time restriction. The latter transect was in a Baumea sedgeland patch with minor variation in vegetation community composition, so three quadrats were considered sufficient in this case. Within each quadrat, the four most dominant plant species, plus all other species with estimated foliage cover $>5 \%$, were identified and percentage foliage cover for the species was visually estimated. Percentage foliage cover was defined as the percentage of the quadrat occupied by the vertical projection of foliage and branches.

Each waterbody transect was surveyed for frogs at night by two persons walking along the transect centreline and recording every frog seen within $1 \mathrm{~m}$ on each side. The same person (JDS) walked in front for all frog surveys, to standardise observer effect. Vegetation was parted where visibility was obscured, to minimise the influence of vegetation density on detectability. Size class and perch substrate were recorded for each wallum sedge frog seen. Two size classes were defined, as per Lewis and Goldingay (2005): snout-vent-length $<16 \mathrm{~mm}$ ('juvenile') and $\geq 16 \mathrm{~mm}$ ('adult'). Perch substrate was recorded, except where it was unknown because the frog was jumping when detected. For vegetative perches, the perch was recorded to the most specific level of identification practical during the surveys. Several upright sedge species (Cyperaceae) were not able to be differentiated during the frog surveys. Instead, upright sedge species were grouped into two types: (i) 'septate', comprising Baumea articulata and Chorizandra spp.; and (ii) 'terete', comprising Baumea rubiginosa, B. teretifolia, Schoenus brevifolius and S. scabripes. Dead parts of plants that were no longer attached to a live plant were regarded as 'debris'. Plants were identified using identification keys of Stanley and Ross $(1983 ; 1986 ; 1989)$ and The Royal Botanic Gardens And Domain Trust (2011).

Surveys were completed during March 2010. The month of March is considered to be a time of high levels of activity and reproduction for the wallum sedge frog (Ehmann 1997; Hopkins 2003). All surveys were completed within a relatively short period (four weeks) to minimise 
Perch substrate use of Litoria olongburensis

variation in seasonal influence between survey areas. All survey areas received substantial rain during the 30 days prior to the surveys, with levels recorded at nearby weather stations in the range $0.22-0.40 \mathrm{~m}$. Rainfall for the 12-month period prior to surveys was not greatly below average for any area, although the second half of 2009 was substantially drier than normal in the Cooloola and Mooloolah River survey areas. Evidence of recent fire was present in two wetlands - one in Cooloola and one in Mooloolah River. These fires may have occurred during the second half of 2009, when conditions were drier than normal. Light rain occurred at some sites during or immediately prior to surveys.

\section{Data analysis}

Waterbodies were treated as sub-samples and combined if proximity and vegetation maps (Griffith et al. 2003; DERM 2005) suggested the waterbodies are part of the same wetland complex with a shared population of wallum sedge frogs that can move freely between the waterbodies. The subsequent sampling unit is referred to hereafter as a 'wetland', which may be composed of one or more waterbodies. Data analysis was restricted to wetlands with at least five adult wallum sedge frogs to reduce the likelihood of apparent substrate association occurring by chance. Only perch substrates that occurred with at least $5 \%$ cover on four or more of those wetlands were examined individually. Other perch substrates were grouped into their structural groups: 'herbaceous plants' or 'shrubs'. Thus, perch substrates examined were 'terete upright sedge species', 'septate upright sedge species', Baloskion pallens (a thin sedge-like herbaceous plant), 'other herbaceous plants' and 'shrubs'. The swamp grasstree, Xanthorrhoea fulva, was included in the herbaceous plants due to its trunkless form.

For each wetland, the proportion of adult wallum sedge frogs observed on each substrate type was calculated from the total for all transects in the wetland. Frogs for which the perch substrate was not known were excluded. The proportion expected on each substrate type was calculated 
Perch substrate use of Litoria olongburensis

from the vegetation foliage cover measures for the transects in the wetland. The proportion of available vegetation for each substrate type was calculated by dividing foliage cover for the substrate type by the total foliage cover for all shrubs and herbaceous vegetation. Tree cover was not included in the calculation because foliage above approximately $2 \mathrm{~m}$ was not searched for frogs. Only a small fraction of shrubs had foliage above $2 \mathrm{~m}$, so the total of shrub and herb cover was considered to adequately represent the vegetation that was searched. For wetlands with more than one transect, foliage cover for each substrate type was calculated using transect averages weighted proportionally to allow for different transect lengths.

The Wilcoxon signed rank test was used to determine whether the proportion of frogs observed on each substrate type was greater or less than the proportion expected $(\alpha=0.05)$. Pairs of values were excluded where the proportion expected was equal to zero, since usage of a substrate type is not possible where it is not present. Differences were ranked using the 'Pratt' method. The tests were performed in $R$ (R-core Development Team 2010) using the wilcox.test function and the wilcoxsign_test function of the coin package version 1.0-18 (Hothorn et al. 2006).

\section{Results}

The perch substrate was observed for five or more adult wallum sedge frogs in 13 wetlands (Table 1). The number of frogs observed in the wetlands ranged from five to 44 (Table 1). All frogs were perched on emergent plants. A high proportion of frogs was perched on the upright Baumea, Schoenus and Chorizandra sedges (Cyperaceae) (75.3\%), or the thin sedge-like Baloskion pallens (Restionaceae) (12.1\%). Small numbers of frogs were perched on shrubs (5.5\%), Xanthorrhoea fulva (3.8\%), Empodisma minus (Restionaceae) (1.1\%) and other herbaceous plants, including Gahnia spp. (2.2\%). No frogs were seen perched on any parts of trees or the small amounts of debris that were present above the water line, and no frogs were in the water when detected. While walking between waterbodies, six adult wallum sedge frogs were 
seen in wallum communities outside wetlands, with the total distance between waterbodies being at least $6.5 \mathrm{~km}$. For these frogs outside wetlands, perch substrate included Xanthorrhoea fulva, Banksia ericifolia, Gahnia and unidentified shrubs (2).

In the 13 wetlands with five or more adult wallum sedge frogs, the proportion of individuals observed on upright sedge species, as a single group, significantly exceeded the proportion expected based on availability (Fig. 2a, Table 2). The proportion observed on the 'terete' subgroup of upright sedges also significantly exceeded the proportion expected (Fig. 2b, Table 2). However, the proportion observed on the 'septate' subgroup of upright sedge species did not differ significantly from the proportion expected $(\mathrm{p}=0.125$, Table 2$)$. Septate upright sedges occurred in only five wetlands, which may have been insufficient for a significant result despite the proportion of frogs observed on the perch type exceeding its availability in four out of five wetlands (Fig. 2c). The proportion of frogs observed on Baloskion pallens was significantly lower than the proportion expected based on availability (Fig. 2d, Table 2). As a group, other herbaceous species were also used significantly less than expected (Fig. 2e, Table 2). In this group, Empodisma minus, Blechnum indicum (swamp water fern) and mosses were most common, while less abundant species included Xanthorrhoea fulva (swamp grasstree), Leptocarpus tenax (Restionaceae), Gahnia sieberiana (saw-sedge) and Sporadanthus caudatus (Restionaceae). The proportion of frogs observed on shrubs was also significantly less than expected (Fig. 2f, Table 2). A wide variety of shrubs occurred in the sites, with Leptospermum liversidgei being the most common and abundant.

\section{Discussion}

Knowledge of habitat usage is lacking for frog species that breed in the acidic waters of coastal 'wallum' (Meyer et al. 2006). The wallum sedge frog has been variously reported to be found among Gahnia sieberana (Ingram and Corben 1975), 'emergent vegetation and reeds' (Liem and 
Ingram 1977), 'sedges and rushes' (Ehmann 1997) and 'sedges, reeds and ferns' (Meyer et al. 2006). Lewis and Goldingay (2005) found that the wallum sedge frog most commonly occurs in 'sedge swamps', which they described as being 'typically ... dominated by Baumea and Restio (now known as Baloskion) sedges ... with an occasional upper stratum comprising wallum bottlebrush (Callistemon pachyphyllus) and broad-leaved paperbark (Melaleuca quinquenervia)'. The present study is the first to quantify usage of individual plant species and structural forms by the wallum sedge frog. During the relatively warm month of March, adult wallum sedge frogs showed a strong tendency to perch on upright sedge species, in particular the group of terete upright sedges (Baumea rubiginosa, B. teretifolia, Schoenus brevifolius and S. scabripes). All other plant groups appear to be mostly avoided.

Many amphibians have colouration that blends with their habitat (Norris and Lowe 1964; Toledo and Haddad 2009). Wallum sedge frogs may be selecting upright sedge species over other available perch types due to a need for camouflage to avoid detection by predators. The wallum sedge frog is a small, slender frog, which appears to blend with the morphology of sedge leaves and culms, while its green or brown colour forms (Lowe and Hero 2012) appear to match the respective green or brown colours of live (green) or dead (brown) leaves and culms of the sedges. Baloskion pallens is terete and upright, but thinner and less robust than the group of upright sedges, possibly making it less suited to the frog's size, shape and colouration. The other herbaceous plants and shrubs found in the study sites also appear to be less suitable for the frog. There are important limitations to the present study. Firstly, the results might not apply to juveniles, as habitat utilisation can differ between adults and juveniles of anurans (Beard et al. 2003). To determine habitat utilisation by juveniles, surveys of juveniles following breeding events are required. Secondly, it is likely that a substantial proportion of adult wallum sedge frogs were not detected during the present study. Six of the study wetlands were being surveyed 
monthly at the time of the present study (Katrin Lowe, unpublished data). These six wetlands were distributed throughout the study area, being at Cooloola (2), Beerwah, Mooloolah, Tyagarah and Yuraygir. Lowe recorded relatively low adult densities during March 2010 at all six sites. Densities four to 10 times higher were recorded at five of the six wetlands during at least one other survey within 40 days of the survey in the present study. A large proportion of individuals therefore appear to have been behaving in an inconspicuous manner during surveys of the present study. Many frog species are known for conspicuous mating behaviour (Wells 1977). The inconspicuous behaviour of individuals in the present study might be associated with non-breeding activities, such as foraging or predator avoidance. Non-breeding activities of the wallum sedge frog are not well understood, and use of habitat by the species may differ from one activity to another. Therefore, the results of the present study might not apply to all forms of behaviour for the wallum sedge frog. Furthermore, the species is known to occur in habitat away from waterbodies. A small number of individuals were recorded away from waterbodies during

the present study. Other authors have also recorded small numbers of individuals in habitat away from waterbodies, including dry heathland (Lewis and Goldingay 2005), Banksia woodland and open eucalypt forest (Hines and Meyer 2011). The species could potentially use habitat several $\mathrm{km}$ from the waterbodies in which it breeds, as has been found with Litoria cooloolensis, which is another 'sedge frog' that breeds exclusively in wallum wetlands (Simpkins et al. 2011). Perch substrate use in non-breeding habitats may be quite different, particularly if non-breeding habitat lacks upright sedges.

\section{Conservation implications}

The mainland areas in which the wallum sedge frog occurs are experiencing rapid growth in human populations with consequent rapid rates of land development. South-east Queensland's human population is approximately 1.7 million and growing at one of the highest rates in 
Australia (Hutson et al. 2008), while coastal areas of northern New South Wales are among the fastest growing areas in that state (DECCW 2009). Effective assessment of impacts on the wallum sedge frog prior to proposed land developments, together with effective control of impacts when developments proceed, are therefore particularly important. The national recovery plan for the species suggests that better understanding of breeding habitat usage is also required so that critical habitat for the species can be defined and subsequently maintained (Meyer et al. 2006). Knowledge of the preferred perch species identified by the present study will assist with identification of important habitat and detection of the species where proposed land development might impact the species. This knowledge will also assist with selection of plant species for habitat to be restored or constructed, such as the ponds created as an attempt to mitigate loss of habitat due to development of the Tugun Bypass at the Gold Coast in southeast Queensland (EcoPro Pty Ltd 2004). In summary, the preferred perch species identified by the present study provide critical information for designing, constructing, restoring and maintaining wetlands that are suitable for the survival and reproduction of the wallum sedge frog.

\section{Acknowledgments}

We thank Clay Simpkins and Mary-Ann Shuker for assistance with data collection. We also thank Ross Goldingay and an anonymous reviewer for suggestions that improved the manuscript. Field surveys were conducted with permission of the New South Wales Department of Environment and Climate Change (license number S12717) and the Queensland Environmental Protection Agency (permit number WITK05620308). Thanks to FKP Pty Ltd \& Griffith University for funding this project. 
Perch substrate use of Litoria olongburensis

\section{References}

Beard, K.H., McCullough, S., and Eschtruth, A.K. (2003). Quantitative assessment of habitat preferences for the Puerto Rican terrestrial frog, Eleutherodactylus coqui. Journal of Herpetology 37(1), 10-17.

DECCW (2009). New South Wales State of the Environment 2009. Department of Environment, Climate Change and Water, Sydney.

DERM (2005). Copy of the certified Regional Ecosystem and Remnant Map - version 6 for the purpose of the Vegetation Management Act 1999. (Department of Environment and Resource Management: Brisbane)

EcoPro Pty Ltd (2004). Tugun Bypass: Species Impact Statement (SIS). A report prepared for the Queensland Department of Main Roads. Department of Main Roads, Brisbane.

Ehmann, H. (1997). Wallum sedgefrog, Litoria olongburensis. In 'Threatened Frogs of New South Wales: Habitats, Status and Conservation.' (Ed. H Ehmann) pp. 182-187. (Frog and Tadpole Study Group of NSW Inc.: Sydney South)

Goldingay, R.L., and Taylor, B.D. (2006). How many frogs are killed on a road in north-east New South Wales. Australian Zoologist 33(3), 332-336.

Griffith, S.J., Bale, C., Adam, P., and Wilson, R. (2003). Wallum and related vegetation on the NSW North Coast: description and phytosociological analysis. Cunninghamia: A Journal of Plant Ecology for Eastern Australia 8(2), 202-252.

Hines, H., Mahony, M., and McDonald, K. (1999). An assessment of frog declines in wet subtropical Australia. In 'Declines and Disappearances of Australian Frogs.' (Ed. A Campbell) pp. 44-63. (Environment Australia: Canberra) 
Perch substrate use of Litoria olongburensis

Hines, H., and Meyer, E. (2011). The frog fauna of Bribie Island: An annotated list and comparison with other Queensland dune islands. Proceedings of the Royal Society of Queensland 117, 261-274.

Hopkins, M.C. (2003). Temporal and spatial distribution of breeding activity in an 'acid' frog community at Tugun, south east Queensland. Honours thesis Thesis, Griffith University, Gold Coast.

Hothorn, T., Hornik, K., van de Wiel, M.A., and Zeileis, A. (2006). A Lego system for conditional inference. The American Statistician 60(3), 257-263.

Hutson, P., Saunders, M., Kohn, P., and Merrick, J. (2008). Population and settlement patterns. In 'State of the Environment Queensland 2007.' pp. 288-299. (Environmental Protection Agency: Brisbane)

Ingram, G.J., and Corben, C.J. (1975). The frog fauna of North Stradbroke Island, with comments on the 'acid' frogs of the Wallum. Proceedings of the Royal Society of Queensland $\mathbf{8 6}$, $49-54$.

Lewis, B.D., and Goldingay, R.L. (2005). Population monitoring of the vulnerable wallum sedge frog (Litoria olongburensis) in north-eastern New South Wales. Australian Journal of Zoology 53(3), 185-194.

Liem, D., and Ingram, G. (1977). Two new species of frogs (Anura: Myobatrachidae, Pelodryadidae) from Queensland and New South Wales. The Victorian Naturalist 94(6), 255-62. Lowe, K., and Hero, J.-M. (2012). Sexual dimorphism and color polymorphism in the wallum sedge frog (Litoria olongburensis). Herpetological Review 43(2), 236-240. 
Lüddecke, H., Amézquita, A., Bernal, X., and Guzmán, F. (2000). Partitioning of vocal activity in a Neotropical highland-frog community. Studies on Neotropical Fauna and Environment 35(3), 185-194.

Meyer, E., Hero, J.-M., Shoo, L., and Lewis, B. (2006). National recovery plan for the wallum sedgefrog and other wallum-dependent frog species. Report to Department of the Environment and Water Resources, Canberra. Queensland Parks and Wildlife Service, Brisbane.

Norris, K.S., and Lowe, C.H. (1964). An analysis of background color-matching in amphibians and reptiles. Ecology 45(3), 565-580.

Parris, K.M. (2001). Distribution, habitat requirements and conservation of the cascade treefrog (Litoria pearsoniana, Anura : Hylidae). Biological Conservation 99(3), 285-292.

R-core Development Team (2010). R: A language and environment for statistical computing. (R Foundation for Statistical Computing: Vienna, Austria). ISBN 3-900051-07-0. Available at http://www.R-project.org/.

Simpkins, C.A., Meyer, E., and Hero, J.-M. (2011). Long-range movement in the rare Cooloola sedgefrog (Litoria cooloolensis). Australian Zoologist 35(4), 977-978.

Stanley, T.D., and Ross, E.M. (1983). 'Flora of south-eastern Queensland. Volume 1.' (Queensland Department of Primary Industries: Brisbane.)

Stanley, T.D., and Ross, E.M. (1986). 'Flora of south-eastern Queensland. Volume 2.' (Queensland Department of Primary Industries: Brisbane.)

Stanley, T.D., and Ross, E.M. (1989). 'Flora of south-eastern Queensland. Volume 3.' (Queensland Department of Primary Industries: Brisbane.) 
Perch substrate use of Litoria olongburensis

The Royal Botanic Gardens And Domain Trust (2011). 'PlantNET - The Plant Information Network System.' Version 2.0. (The Royal Botanic Gardens and Domain Trust: Sydney.) Available at http://plantnet.rbgsyd.nsw.gov.au [Verified June 2011]

Toledo, L.F., and Haddad, C.F.B. (2009). Colors and some morphological traits as defensive mechanisms in anurans. International Journal of Zoology 2009(Article ID 910892).

Watson, J., McAllister, K., and Pierce, D. (2003). Home ranges, movements, and habitat selection of Oregon spotted frogs (Rana pretiosa). Journal of Herpetology 37(2), 292-300.

Wells, K.D. (1977). The social behaviour of anuran amphibians. Animal Behaviour 25(Part 3), 666-693. 
Perch substrate use of Litoria olongburensis

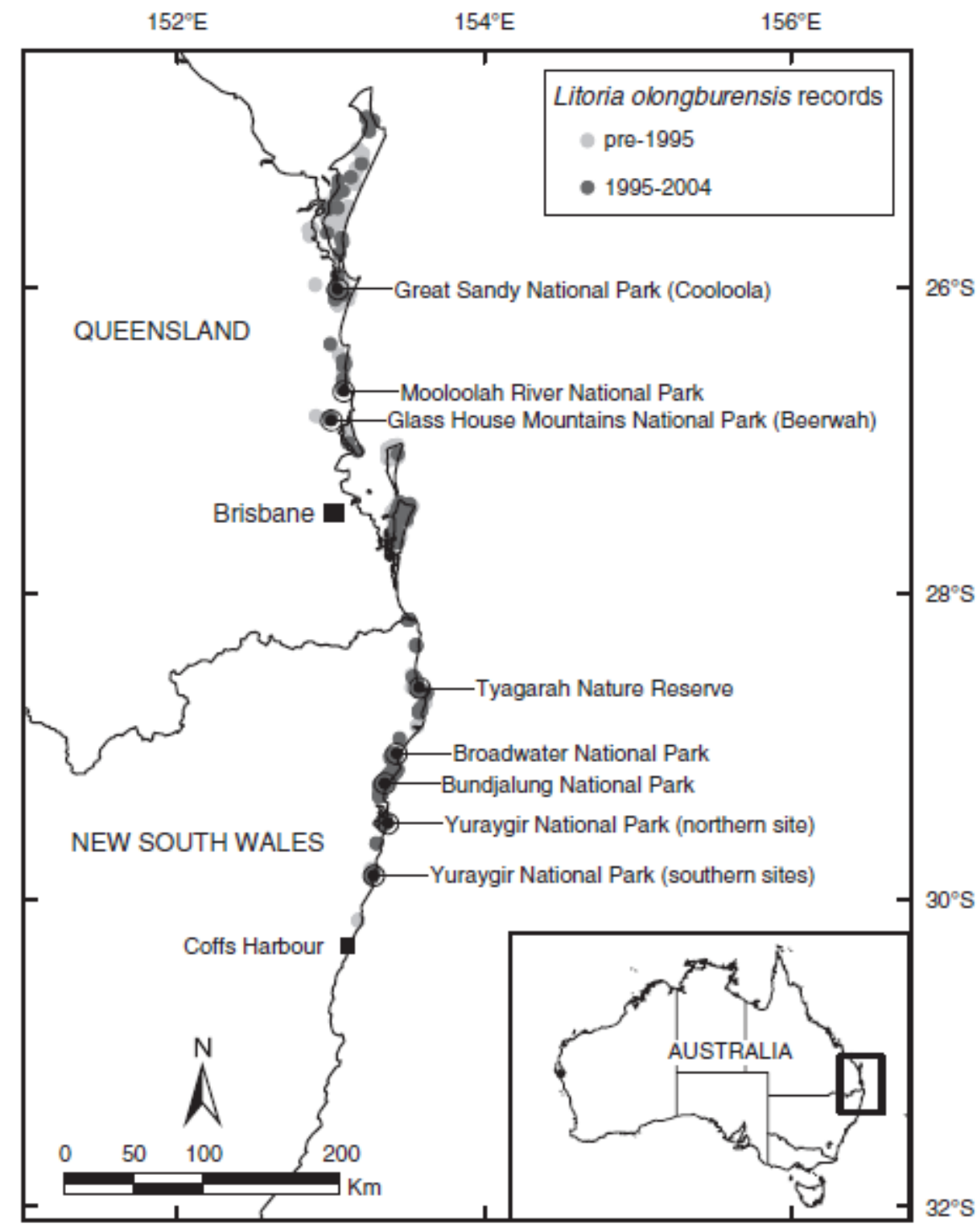

Fig. 1. Distribution of L. olongburensis (Source of species records: Meyer et al. 2005), and location of areas where surveys were conducted for the present study. 
Table 1. Details of wetland sites occupied by five or more adult wallum sedge frogs

NP = National Park. The sampling unit is a 'wetland', which represents a single population of the wallum sedge frog. One or more wetlands were found along each search line. Each wetland contained one or more waterbodies occupied by adult wallum sedge frogs. The total length of survey transects in waterbodies of each wetland is shown, along with the number of frogs for which perch substrate was recorded in the wetland.

\begin{tabular}{|c|c|c|c|c|c|c|}
\hline $\begin{array}{l}\text { Survey area } \\
\text { (in latitudinal order) }\end{array}$ & $\begin{array}{l}\text { Search line } \\
\text { length } \\
(\mathrm{km})\end{array}$ & $\begin{array}{l}\text { Wetland } \\
\text { \# }\end{array}$ & $\begin{array}{l}\text { Distance to } \\
\text { nearest other } \\
\text { wetland in } \\
\text { survey area } \\
\quad(\mathrm{km})\end{array}$ & $\begin{array}{l}\text { No. of } \\
\text { waterbodies } \\
\text { occupied by } \\
\text { adult frogs }\end{array}$ & $\begin{array}{l}\text { Total } \\
\text { transect } \\
\text { length } \\
(\mathrm{m})\end{array}$ & $\begin{array}{l}\text { No. of } \\
\text { adult } \\
\text { frogs } \\
\text { recorded }\end{array}$ \\
\hline \multirow[t]{3}{*}{ Great Sandy NP (Cooloola section) } & \multirow[t]{3}{*}{2.19} & 1 & 0.8 & 1 & 200 & 8 \\
\hline & & 2 & 0.8 & 1 & 88 & 6 \\
\hline & & 3 & 1.4 & 1 & 154 & 8 \\
\hline Mooloolah River National Park & 1.04 & 1 & - & 1 & 280 & 10 \\
\hline Glass House Mtns NP (Beerwah) & 1.11 & 1 & - & 3 & 466 & 18 \\
\hline Tyagarah Nature Reserve & 0.40 & 1 & - & 2 & 177 & 19 \\
\hline Broadwater National Park & 0.78 & 1 & - & 2 & 171 & 15 \\
\hline \multirow[t]{3}{*}{ Bundjalung National Park ${ }^{\mathrm{A}}$} & 0.35 & 1 & 4.4 & 1 & 76 & 9 \\
\hline & \multirow[t]{2}{*}{1.57} & 1 & 0.7 & 2 & 300 & 44 \\
\hline & & 2 & 0.7 & 1 & 316 & 27 \\
\hline Yuraygir National Park (northern) & 0.79 & 1 & - & 1 & 64 & 7 \\
\hline \multirow[t]{2}{*}{ Yuraygir National Park (southern) ${ }^{\mathrm{B}}$} & 1.10 & 1 & 9.6 & 1 & 303 & 5 \\
\hline & 1.14 & 1 & 9.6 & 2 & 243 & 6 \\
\hline
\end{tabular}

${ }^{\mathrm{A}} 2$ search lines, $4.4 \mathrm{~km}$ apart

в 2 search lines, $9.6 \mathrm{~km}$ apart 
(a) All upright sedges

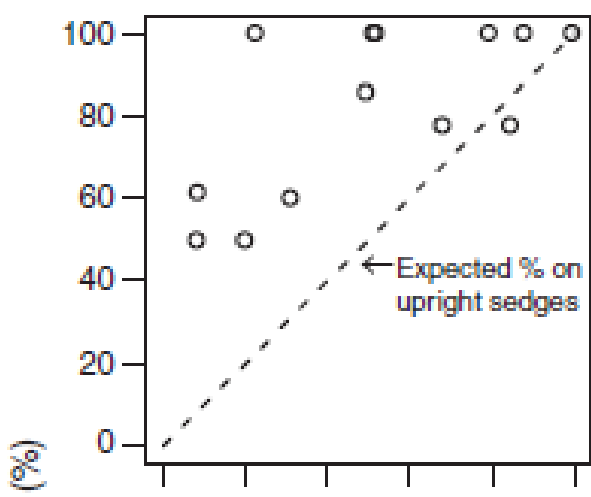

(d) Baloskion pallens

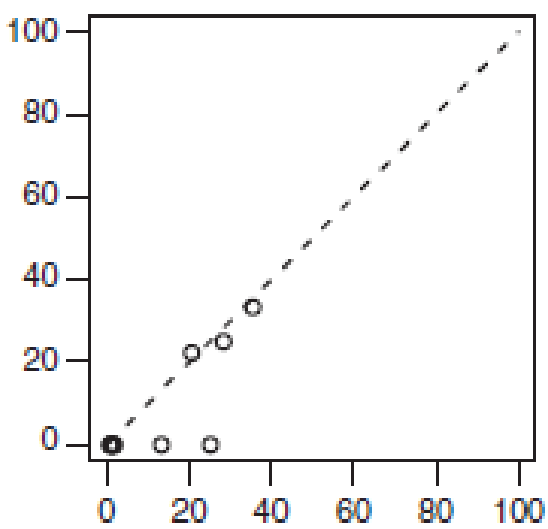

(b) Terete upright sedges

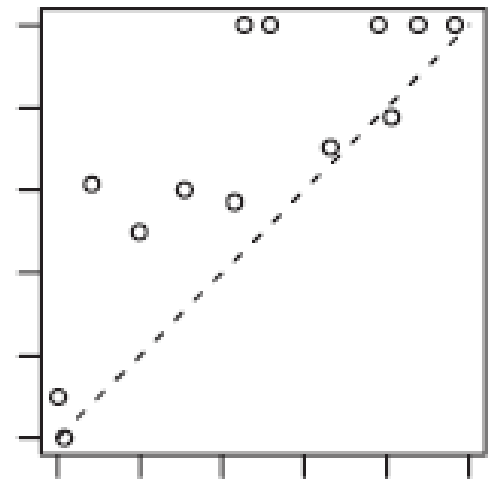

(e) Other herbaceous spp.

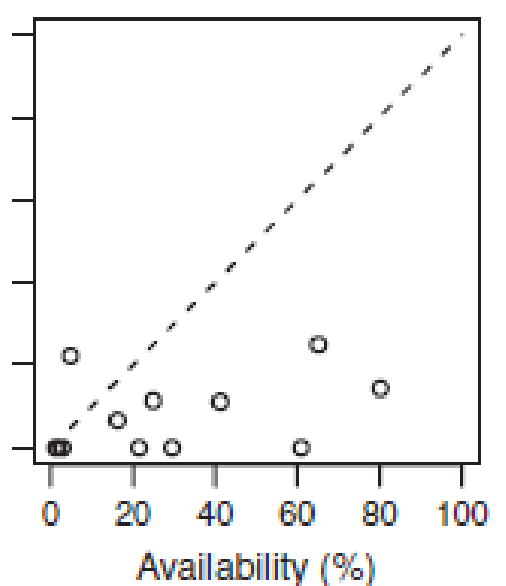

(c) Septate upright sedges

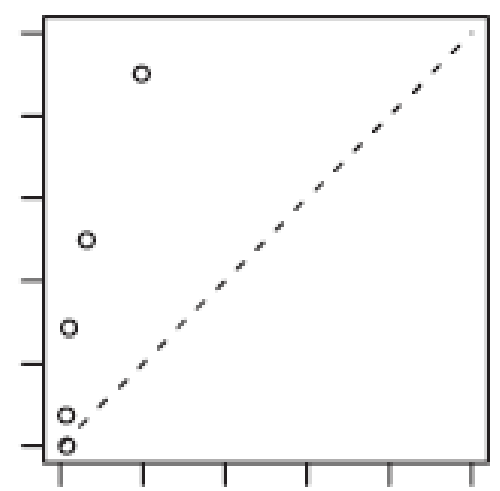

(f) Shrubs

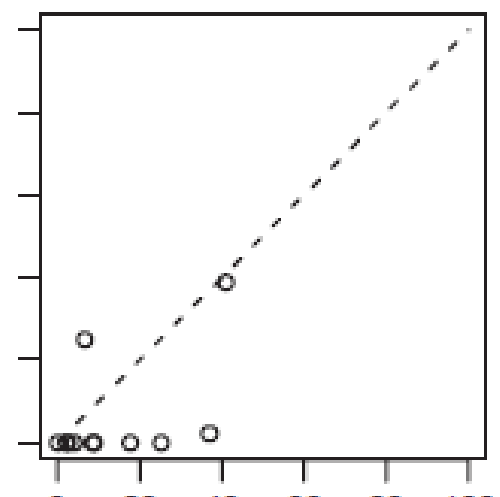

$\begin{array}{llllll}0 & 20 & 40 & 60 & 80 & 100\end{array}$

Fig. 2. Proportion (\%) of adult wallum sedge frogs perched on each substrate versus the proportion $(\%)$ of available cover contributed by the substrate. Only wetlands with five or more observed adults are shown. Data points with availability equal to zero have been excluded. The dashed line represents the expected unbiased response, where the proportion of frogs perched on the substrate equals the proportion of available cover contributed by the substrate. 
Table 2. Results of tests comparing observed and expected usage of perch substrates based

\section{on availability}

$\mathrm{W}=$ Wilcoxon test statistic. For each substrate group, a two-sided Wilcoxon signed-rank test compared observed usage with expected usage across all sites $(n=13)$.

\begin{tabular}{lcrrr}
\hline $\begin{array}{l}\text { Form: } \\
\text { Group/Species }\end{array}$ & $\begin{array}{c}\text { No. of sites } \\
\text { where present }\end{array}$ & W & Z & p-value \\
\hline Herbaceous: & & & & \\
$\quad$ Upright sedge spp.: & & & & \\
$\quad$ All & 13 & 89 & 3.040 & 0.0007 \\
$\quad$ Terete & 13 & 88 & 2.970 & 0.0012 \\
$\quad$ Septate & 5 & 14 & 1.753 & 0.1250 \\
$\quad$ Baloskion pallens (Restionaceae) & 10 & 5 & -2.293 & 0.0195 \\
$\quad$ Other herbaceous spp. & 13 & 7 & -2.691 & 0.0046 \\
Shrubs & 12 & 10 & -2.275 & 0.0210 \\
\hline
\end{tabular}

